\title{
An Atypical Presentation of a Colonic Lipoma: Avoiding Surgery with a Deeper Endoscopic Look
}

\author{
Mafalda João ${ }^{a}$ Inês Cunha ${ }^{b}$ Elisa Gravito-Soares ${ }^{b, c}$ Marta Gravito-Soares ${ }^{b, c}$ \\ Pedro Amaro $^{\mathrm{b}}$ Pedro Figueiredo $^{\mathrm{b}, \mathrm{c}}$ \\ ${ }^{a}$ Gastroenterology Department, Instituto Português de Oncologia Francisco Gentil, Coimbra, Portugal; \\ ${ }^{\mathrm{b}}$ Gastroenterology Department, Centro Hospitalar e Universitário de Coimbra, Coimbra, Portugal; ' University of \\ Coimbra, Faculty of Medicine, Coimbra, Portugal
}

\section{Keywords}

Colonic lipoma $\cdot$ Intussusception $\cdot$ Single-incision needle-knife biopsy technique

\section{Abstract}

Introduction: Colonic lipomas are common mesenchymal tumours. They are usually asymptomatic and incidentally diagnosed during endoscopic or radiological examinations. Taking into account their typical endoscopic and radiological features and benign nature, tissue sampling, resection or follow-up are generally not required. Case Report: A 61-yearold woman with poor surgical fitness presented with colonic subocclusion and lower gastrointestinal bleeding. A colonoscopy performed 1 month earlier showed a large polypoid lesion with necrotic and ulcerated areas occupying the lumen of the proximal ascending colon with inconclusive histology. An abdominopelvic computed tomography scan with intravenous contrast was done revealing a cecal-colonic intussusception of a heterogeneous mass. The patient was successfully managed conservatively. A delayed revision colonoscopy showed a significantly smaller atypical subepithelial lesion with no necrosis or ulceration. A single, large and deep incision with a pre-cut needle-knife ${ }^{\circledR}$ allowed the direct collection of lesion tissue using standard biopsy forceps through the so-called single-incision needle-knife ${ }^{\circledR}$ (SINK) biopsy technique. Histological examination was compatible with submucosal lipoma. After 18 months of followup, the patient remains asymptomatic. Discussion/Conclusion: Colonic lipoma complications are rare and can lead to misdiagnosis; in general, they are surgically managed. A conservative approach and a minimally invasive endoscopic procedure allowed a definite diagnosis avoiding the morbidity and mortality of a major surgical intervention in a highrisk patient.

\footnotetext{
(c) 2021 Sociedade Portuguesa de Gastrenterologia Published by S. Karger AG, Basel
}

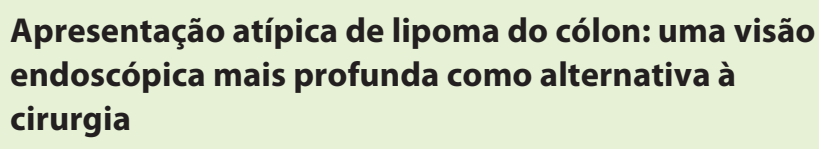

Palavras Chave

Lipoma do cólon · Invaginação · Biopsia por faca-agulha de pré-corte de incisão única

\section{(c) 2021 Sociedade Portuguesa de Gastrenterologia} Published by S. Karger AG, Basel

This is an Open Access article licensed under the Creative Commons Attribution-NonCommercial-4.0 International License (CC BY-NC) (http://www.karger.com/Services/OpenAccessLicense), applicable to the online version of the article only. Usage and distribution for commercial purposes requires written permission.
Mafalda João

Gastroenterology Department, Instituto Português de Oncologia Francisco Gentil Av. Prof. Dr. Bissaya Barreto ${ }^{\circ} 98$ PT-3000-075 Coimbra (Portugal) mafaldacaine@gmail.com 


\section{Resumo}

Introdução: Os lipomas do cólon são tumores mesenquimatosos comuns. Frequentemente são assintomáticos e diagnosticados, incidentalmente, em exames endoscópicos e imagiológicos. O diagnóstico histológico, resseção e vigilância não costumam ser necessários devido aos achados endoscópicos e imagiológicos típicos e à sua natureza benigna. Caso clínico: Uma mulher de 61 anos com contraindicação relativa para cirurgia abdominal recorreu ao serviço de urgência por quadro clínico de suboclusão intestinal e hemorragia digestiva baixa. A colonoscopia, realizada um mês antes, demonstrava uma lesão polipoide com área de necrose e ulceração a ocupar o lúmen do cólon ascendente proximal, com estudo histológico inconclusivo. Foi efetuada uma tomografia computorizada abdominopélvica com contraste intravenoso que revelou uma invaginação ceco-cólica de uma massa heterogénea. Optou-se por uma abordagem conservadora com remissão clínica. A colonoscopia de revisão diferida mostrou, na mesma localização, uma lesão subepitelial de menores dimensões, atípica, sem ulceração ou necrose. Com uma faca-agulha de pré-corte foi efetuada uma incisão única e profunda que permitiu a colheita direta de material usando uma pinça de biopsias standard através da técnica denominada biopsia por faca-agulha de précorte de incisão única. A análise histológica foi compatível com lipoma submucoso. Cerca de 18 meses após o episódio a doente permanece assintomática. Discussão/ Conclusão: As complicações do lipoma do cólon são raras e podem levar a um diagnóstico erróneo, geralmente tratado cirurgicamente. Uma abordagem conservadora inicial e um procedimento endoscópico minimamente invasivo permitiram o diagnóstico definitivo, evitando a morbilidade e mortalidade associadas a uma intervenção cirúrgica major numa doente de alto risco.

(C) 2021 Sociedade Portuguesa de Gastrenterologia Publicado por S. Karger AG, Basel

\section{Introduction}

Subepithelial lesions (SELs) represent abnormal growing tissue underneath the normal mucosa of the gastrointestinal tract. Lipomas are common SELs found throughout the gastrointestinal tract, most commonly in the colon and gastric antrum. They are collections of adipose tissue, arising mostly from the submucosal layer, which often display a yellowish hue on endoscopy and are soft on forceps probing $[1,2]$. Demonstration of a "pillow sign" or indentation on probing is $98 \%$ specific for the diagnosis [1-3]. Usually, lipomas are asymptomatic and incidentally diagnosed during endoscopic or radiologic examinations. They also have negligible malignant potential. However, in rare cases, large lesions may develop complications, including bleeding or obstruction. Therefore, unless tumours are symptomatic or atypical, tissue sampling, resection or surveillance are not required after endoscopic presumptive diagnosis. Nonetheless, when recommended, tissue acquisition can be quite challenging, often leading to consecutive inconclusive attempts caused by the difficulty in reaching the deep-seated target lesion.

The authors present this case not only for its rarity and striking iconography, but also for the diagnostic challenge and consequent implication on therapeutic decision-making that it may represent.

\section{Case Report}

A 61-year-old Caucasian woman presented for colonoscopy due to lower abdominal discomfort that had been present for the last 6 months. She denied other associated symptoms. Her surgical history was relevant for hysterectomy with bilateral oophorectomy performed 2 years earlier complicated by a large incisional hernia that had to be submitted to surgical correction twice. A colonoscopy was performed revealing a large polypoid lesion with necrotic and ulcerated areas almost completely occluding the lumen of the proximal ascending colon (Fig. 1); the cecum could not be evaluated. Biopsies obtained using standard biopsy forceps were inconclusive.

One month later, she was admitted to the emergency department with abdominal pain and distension, constipation and hematochezia. An abdominopelvic computed tomography scan with intravenous contrast showed a cecal-colonic intussusception of a 54$\mathrm{mm}$ heterogeneous mass with no fatty densitometric value, without signs of complete occlusion (Fig. 2). An urgent surgical approach was considered. However, due to the high risk of postoperative wound complications related to previous recurrent incisional hernia repair, a multidisciplinary team involving surgeons and gastroenterologists decided for a conservative approach with bowel rest, intravenous fluids and symptomatic therapy.

A progressive clinical improvement was verified without symptomatic recurrence and tolerance for introduction of oral feeding and progression to a low-fiber diet.

The patient was scheduled for a delayed revision colonoscopy that showed a significantly smaller atypical subepithelial lesion without necrosis or ulceration. A single, large and deep incision with a pre-cut needle-knife ${ }^{\circledR}$ (KD-10-Q-1, Olympus, Tokyo, Japan) allowed the protrusion of a soft yellow lesion and tissue sampling acquisition using standard biopsy forceps through the socalled single-incision needle-knife ${ }^{\circledR}$ (SINK) biopsy technique (Fig. 3). There were no procedure-related complications and the patient was discharged on the same day. The microscopic examination was compatible with a submucosal colonic lipoma without fat necrosis, granulation or ulceration (Fig. 4). Taking into account
João et al. 


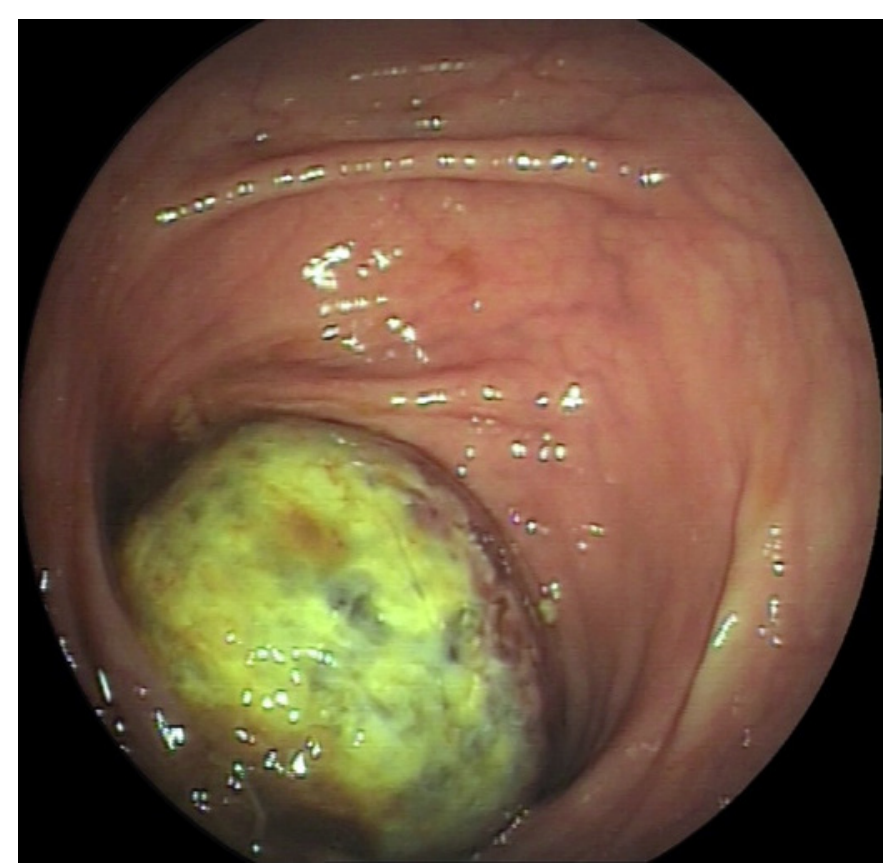

Fig. 1. Initial colonoscopy showing a 30-35-mm polypoid lesion with necrotic and ulcerated areas occupying three quarters of the lumen of the proximal ascending colon.

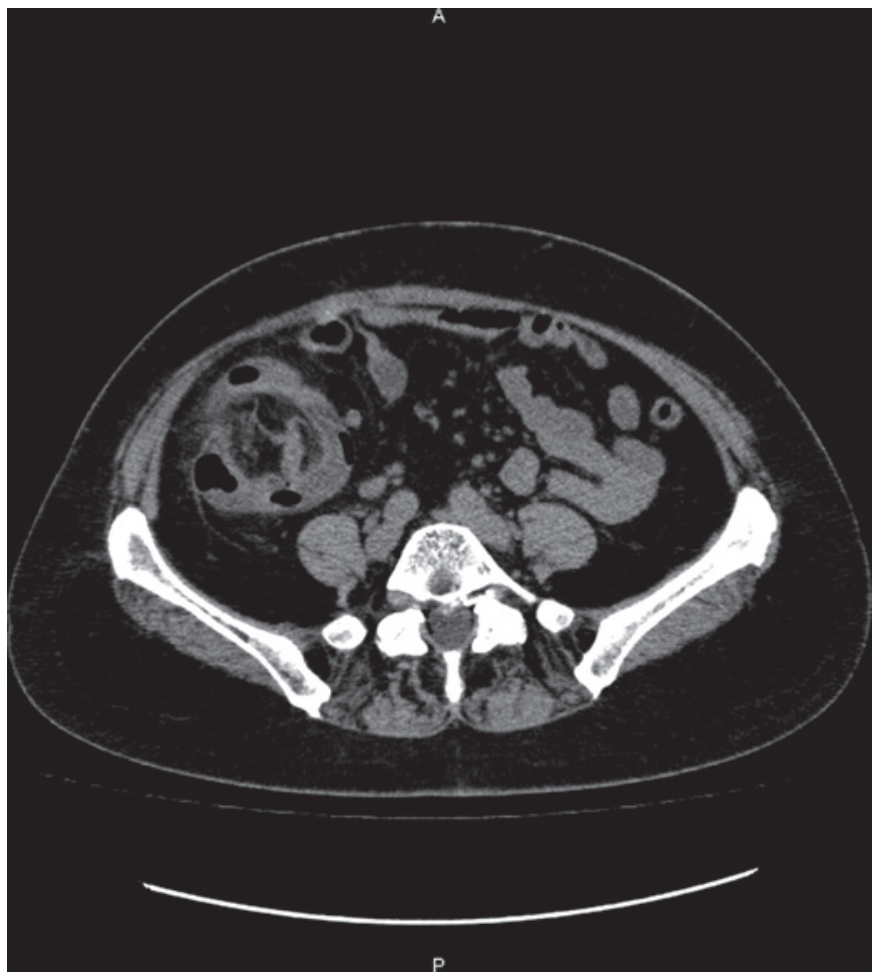

Fig. 2. Abdominopelvic computed tomography scan with intravenous contrast (axial section) demonstrating a ceco-colonic intussusception with invaginated mesenteric fat and vessels.
Fig. 3. At the revision colonoscopy, a 10$\mathrm{mm}$ linear incision created by needleknife $^{\circledR}$, over the highest convexity of the lesion, exposed the target-lesion at the deeper layers. Lesion tissue sampling was obtained using a standard biopsy forceps through the SINK technique.
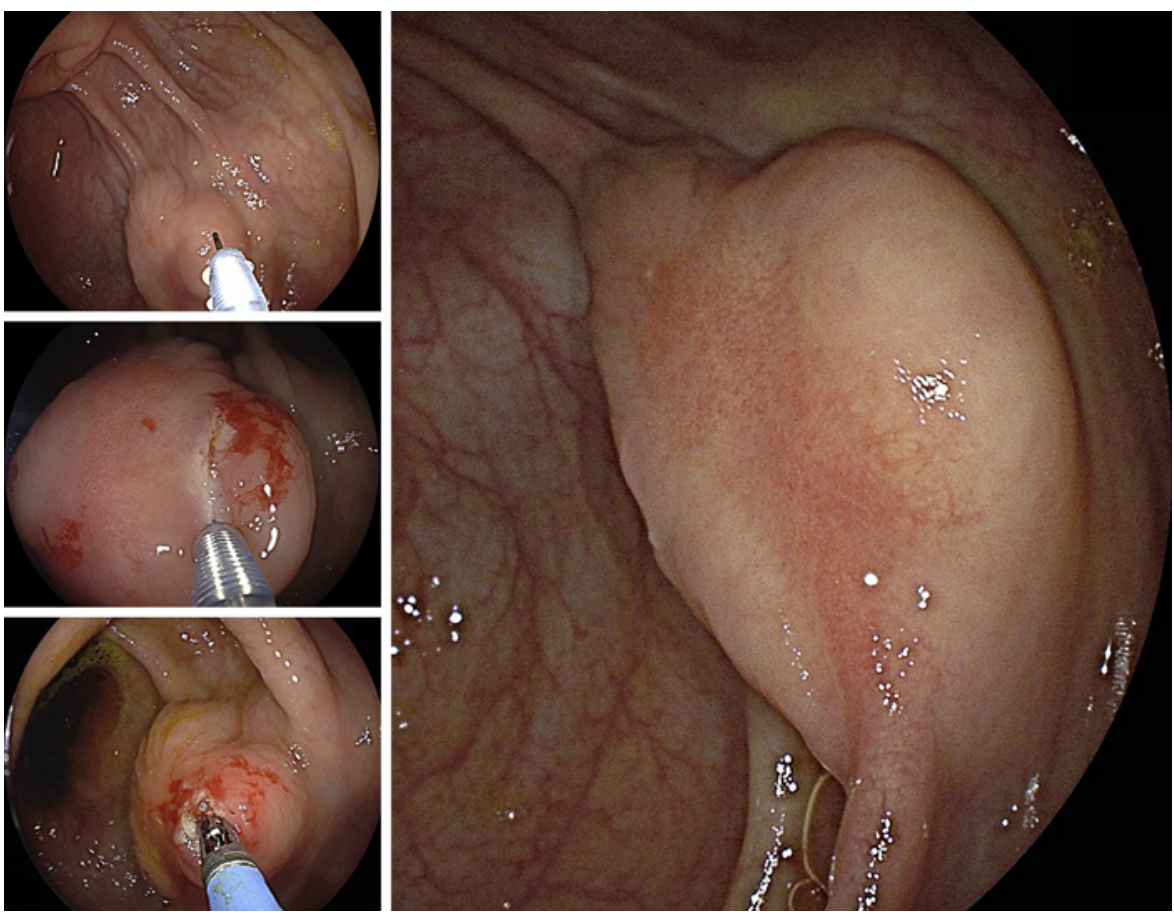
Fig. 4. Histological examination revealing small fragments of mature adipose tissue with connective bundles and vessels without fat necrosis, granulation or ulceration, compatible with a submucosal colonic lipoma.

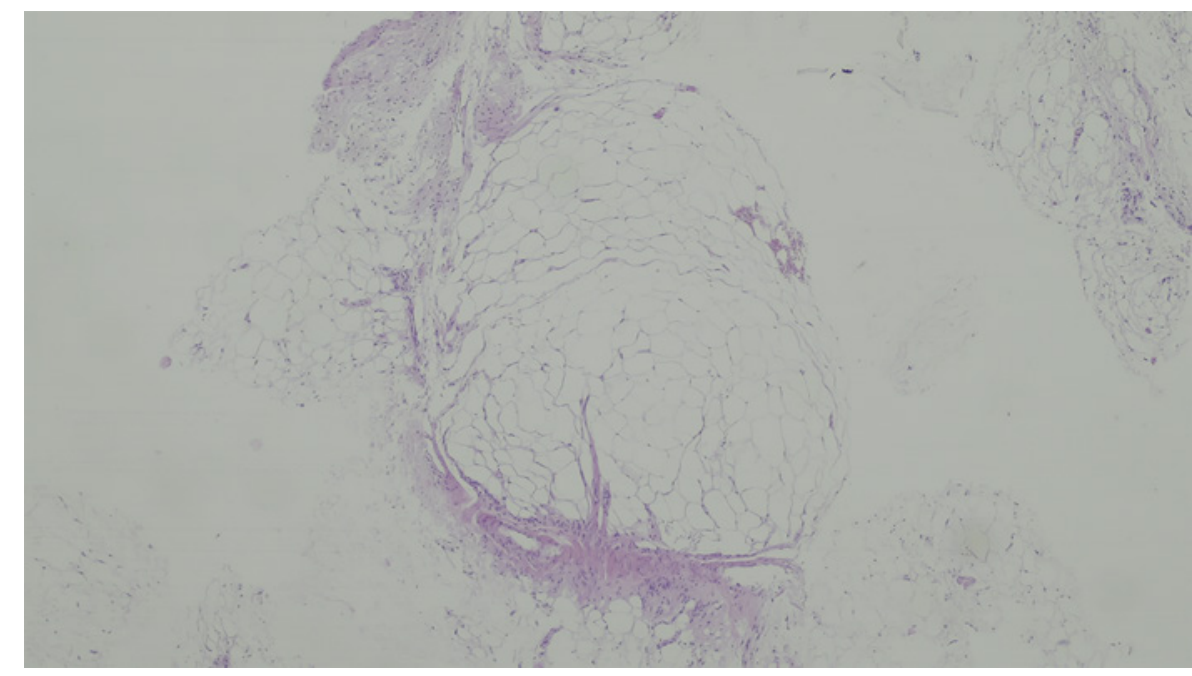

the concerns about a major abdominal surgery, the benign nature of the lesion and the present low risk of intussusception/occlusion due to the considerable spontaneous reduction in lesion size (probably due to necrosis), it was decided to follow-up. The patient remains asymptomatic after 18 months.

\section{Discussion/Conclusion}

Gastrointestinal lipomas are benign mesenchymal tumours that arise from the submucosa in $90 \%$ of cases. They have an incidence between 0.2 and $4.0 \%$. About $70 \%$ are located in the colon, with the right colon and the ileocecal valve being the most frequent location. The median age at the time of diagnosis ranges from 50 to 69 years, with female predominance. They are usually asymptomatic and incidentally diagnosed during diagnostic procedures, surgery or autopsy $[1,2]$. However, lipomas larger than $4 \mathrm{~cm}$ can become symptomatic and develop complications, such as abdominal pain, bleeding, colonic obstruction and intussusception [4]. The intussusception is a rare complication that occurs more frequently in the small bowel than in the colon and that imposes a diagnostic dilemma requiring a differential diagnosis with malignant lesion and other benign lesions, either epithelial or subepithelial [5-7]. This is even more challenging in patients with poor surgical fitness (considerer: relative surgical contra-indication), as in the present case, where the preoperative diagnosis is crucial to decision-making.

A yellowish hue on endoscopy soft on forceps probing and an ultrasonography appearance as homogeneous, well-defined hyperechoic lesion arising from the submu- cosal layer are typical features, making tissue sampling not required. Computed tomography is usually helpful in typical cases, revealing a mass with a characteristic fatty densitometric value that supports the diagnosis $[1,2]$. However, lipomas complicated with intussusception, as in the reported case, present as a complex mass showing loss of fat density or entirely soft-tissue attenuation, making the differential diagnosis based on imaging features difficult [8].

SELs with atypical features, such as heterogeneous features on imaging, or a complicated clinical course, as in this case, require tissue acquisition for diagnostic workup. Because of their deep location to the epithelial layer, tissue sampling is usually challenging. Several techniques with suboptimal diagnostic yields have been described. These include standard biopsy forceps, "bite-onbite biopsy," jumbo biopsy, endoscopic ultrasoundguided fine-needle aspiration (EUS-FNA), endoscopic ultrasound-guided fine-needle biopsy (EUS-FNB), endoscopic resection and/or ligation, tunnelling or unroofing techniques and surgery $[1,2]$. European guidelines suggest performing "byte-on-byte" biopsy, as the first diagnostic procedure for SELs. If inconclusive, EUS-guided sampling or advanced endoscopic techniques are valid alternatives for tissue obtaining [7]. Standard or 'biteon-bite' mucosal biopsies have a disappointing diagnostic yield up to $38 \%$. Jumbo forceps slightly increase the diagnostic yield, but also the bleeding rate. $\mathrm{Di}$ agnostic accuracies of EUS-FNA and EUS-FNB range widely from 46 to $93 \%$, depending on lesion features (size, location and type), size of needle used, biopsy technique, the availability of on-site cytology review, and
João et al. 
whether or not a stylet or suction are used. In the described case, the lesion location precluded EUS and miniprobes that could help on the diagnosis, do not provide histology sampling per se. Endoscopic resection and tunnelling techniques are advanced procedures that allow variable complete resection rates (78-100\%). However, concerns about the risk of perforation, bleeding, tumour spillage and high clinical expertise make their widespread application for SELs resection controversial $[1,9]$. Unroofing of a SEL removes the overlying mucosa and possibly allows partial resection of the lesion, thereby improving access to the deeper layers [10]. Unroofing can be performed with a needle-knife, snare, cap or banding device. A SINK technique, recently described by Serna-Higuera et al. [11], was performed in this case. A needle-knife created a 10-mm linear incision over the highest convexity of the lesion, after which standard biopsy forceps was used to obtain tissue from the target-lesion located at the deeper layers. The diagnostic yield of this technique varies from 86 to $96 \%$. A variation of this technique was also described to resect SELs lesser than $3 \mathrm{~cm}$, mostly in the upper gastrointestinal tract [6]. Most reported complications associated with this technique were minor bleeding (56\%) and the development of perilesional fibrosis which can hamper subsequent endoscopic resection attempts $[1,12,13]$. In conclusion, SINK technique is a simple and useful minimal invasive method of tissue acquisition for atypical SLEs and even resection under specific conditions. This technique ensures a good balance between efficacy and safety with a high diagnostic accuracy and low-risk safety profile, especially for high surgical risk patients, in whom the definitive preoperative diagnosis is crucial to avoid an unnecessary major surgery. Surgical resection is only reserved for failure of diagnostic endoscopic techniques, incomplete endoscopic resection of potentially malignant lesions, expansion into the muscle layer and serosa or intussusception-induced occlusion. Historically, intussusception had been treated surgically due to the association of pathology serving as lead point. Literature on the conservative approach of this complication is scarce. In the reported case, we describe a conservative approach successfully applied of a non-occlusive intussusception in a high surgical risk patient. A spontaneous resolution of the lesion intussusception was verified with regression of the lesion size and ischemic features. One likely mechanism to explain lesion regression is the ischemia with consequent necrosis resulting from peristaltic contractions of the intussuscepted bowel against obstruction or twist of the lesion around itself $[5,14,15]$.

An Atypical Presentation of a Colonic Lipoma
Colonic lipoma presentation as an intussusception resulting in an acute colonic subocclusion usually requires surgically resection for diagnostic and therapeutic purposes. This case illustrates a rare complication of a colonic lipoma conservatively managed in a high-risk patient highlighting the effectiveness and safety of SINK technique in providing an accurate preoperative diagnosis. This minimal invasive endoscopic technique changed decision-making and avoided a major surgery with possible non-negligible morbidity.

\section{Acknowledgements}

The authors would like to thank Dr. Rui Caetano Oliveira for his kindness in providing histopathological images.

\section{Statement of Ethics}

Protection of human and animal subjects: The authors declare that no experiments were performed on humans or animals for this study. Confidentiality of data: The authors declare that they have followed the protocols of their work center on the publication of patient data. Right to privacy: the authors declare that no patient data appear in this article. Informed patient consent for publication: informed consent was obtained for this case report.

\section{Conflict of Interest Statement}

The authors have no conflicts of interest to declare.

Funding Sources

No funding was received.

\section{Author Contributions}

Inês Cunha and Mafalda João contributed equally in writing the manuscript and reviewing the literature. Elisa Gravito-Soares and Pedro Amaro contributed in performing the procedure, acquisition of data and critically reviewed the manuscript. Marta Gravito-Soares and Pedro Figueiredo contributed to critical revision of the manuscript for important intellectual content. All authors approved the published version of the study and agreed to be accountable for all aspects of the work ensuring questions related to the accuracy or integrity of any part of the work were appropriately evaluated and resolved. 


\section{References}

1 Faulx AL, Kothari S, Acosta RD, Agrawal D, Bruining DH, Chandrasekhara V, et al.; Standards of Practice Committee. The role of endoscopy in subepithelial lesions of the GI tract. Gastrointest Endosc. 2017 Jun;85(6): 1117-32.

2 Rodríguez-de-Santiago E, Frazzoni L, Fuccio L, van Hooft JE, Ponchon T, Hassan C, et al. Digestive findings that do not require endoscopic surveillance - Reducing the burden of care: European Society of Gastrointestinal Endoscopy (ESGE) Position Statement. Endoscopy. 2020 Jun;52(6):491-7.

3 Barbeiro S, Martins C, Gonçalves C, Arroja B, Canhoto M, Silva F, et al. Schwannoma-A Rare Subepithelial Lesion of the Colon. GE Port J Gastroenterol. 2015 Mar;22(2):70-4.

$4 \mathrm{Kim}$ TO. Colorectal Subepithelial Lesions. Clin Endosc. 2015 Jul;48(4):302-7.

5 González-Urquijo M, Kettenhofen SE, Rodarte-Shade M. Colonic intussusception by a giant colon lipoma: A case report. International Journal of Surgery Open. 2017;9:7-9.
6 Tomiki Y, Niwa K, Nagayasu K, Okazawa Y, Ito $\mathrm{S}$, Ichikawa $\mathrm{R}$, et al. Two Patients with Large Colonic Lipomas for which Endoscopic Unroofing was Ineffective. Case Rep Gastroenterol. 2016 Oct;10(3):538-44.

7 Costeira Filipa de S. Gonçalves M, Esteves C, Rebelo A, Leite C: Colonic Lipoma as a Cause of Colocolic Intussusception. GE Port J Gastroenterol. 2020:1-3.

8 Thompson WM. Imaging and findings of lipomas of the gastrointestinal tract. AJR Am J Roentgenol. 2005 Apr;184(4):1163-71.

9 Kim SY, Kim KO. Endoscopic Treatment of Subepithelial Tumors. Clin Endosc. 2018 Jan; 51(1):19-27.

10 Kopáčová $\mathrm{M}$, Rejchrt $\mathrm{S}$, Bureš J. Unroofing Technique as an Option for the Endoscopic Treatment of Giant Gastrointestinal Lipomas. Acta Med (Hradec Kralove). 2015;58(4): $115-8$.
11 de la Serna-Higuera C, Pérez-Miranda $M$, Díez-Redondo P, Gil-Simón P, Herranz T, Pérez-Martín E, et al. EUS-guided single-incision needle-knife biopsy: description and results of a new method for tissue sampling of subepithelial GI tumors (with video). Gastrointest Endosc. 2011 Sep;74(3):672-6.

12 Shimamura Y, Hwang J, Cirocco M, May GR, Mosko J, Teshima CW. Efficacy of single-incision needle-knife biopsy for sampling subepithelial lesions. Endosc Int Open. 2017 Jan; 5(1):E5-10.

13 Johns E, Binmoeller KF. Subepithelial lesions: a deeper look. Gastrointest Endosc. 2016 Dec; 84(6):930-2.

14 Ávila F, Pereira JR, Duarte MA. Colonic Intussusception Caused by Colonic Lipoma. GE Port J Gastroenterol. 2016 Jun;23(5):264-6.

15 Marsicovetere P, Ivatury SJ, White B, Holubar SD. Intestinal Intussusception: Etiology, Diagnosis, and Treatment. Clin Colon Rectal Surg. 2017 Feb;30(1):30-9. 